\title{
Que los conflictos no escalen a la violencia
}

Por Denis Torres ${ }^{1}$

$\mathrm{N}$ podemos evitar los conflictos, pero si la violencia. Los conflictos son naturales a toda comunidad humana: familia, barrio, comunidad nacional e internacional, empresas, incluso hasta las mismas iglesias ¿por qué? Porque existen intereses materiales e inmateriales diferentes. Cuando existen recursos limitados ante esos intereses, o percepciones de que mis valores e identidades culturales no son respetados ni reconocidos, surge la divergencia, el antagonismo y el conflicto.

Los conflictos pueden ser hasta saludables, depende de cómo los abordamos y gestionamos. Si los administramos de manera pacífica y creativa, la superación del mismo habrá hecho crecer a la comunidad en todos los sentidos y la superación del conflicto será duradera. Habrá vencido la paz, la palabra, el encuentro. El otro camino es la violencia, que en definitiva, empobrece, hace del conflicto un fenómeno recurrente, más tarde o más temprano, pues habrá quedado una parte de la comunidad con el germen del rencor y la venganza. La propia Segunda Guerra Mundial se dio teniendo de caldo de cultivo el sentimiento nacional alemán herido por el contenido humillante de los acuerdos de Versalles que puso fin a la Primera Guerra, pero, ¿le puso fin de verdad?... para mencionar casos actuales controversiales, ¿habrá sido necesario entrar hasta ahora a una negociación política, cuando Siria ha sido destruida y vuelta a la era de las cavernas?

Muchos gobiernos cuando llegan o dejan el poder, elaboran y actúan teniendo en cuenta un mapeo de la conflictividad del país: laboral, política, social, etc; para así estudiarlos, comprenderlos, abordarlos y superarlos. Algunos heredan a otros parte de esa conflictividad.
El cambio de gobierno y de régimen producido en 1990 generó un sinfín de conflictos violentos dada la naturaleza y modalidad de aquellos cambios: realzamientos militares, huelgas, asonadas callejeras, secuestros, etc. Sin embargo, la mayoría de ellos fueron abordados y superados sin mayor derramamiento de sangre, otros fueron heredados al siguiente gobierno.

Para ejemplificar con hechos de nuestro ámbito (educativo), la lucha ética y jurídica por el 6 \%comenzó en el gobierno de doña Violeta, con su costo humano, académico y material, continuó en el gobierno de Alemán, con refriegas cotidianas que hacían pensar fuera del país que Nicaragua seguía en guerra, con los costos para la inversión que ello implicaba.

En 1999, la UPOLI se aprestaba a otorgar el Dr. Honoris Causa al Director General de la UNESCO, Federico Mayor Zaragoza. Esa noche fruto de los enfrentamientos entre el movimiento universitario y la Policía, murió un estudiante en la propia biblioteca del Banco Central. El profesor Federico Mayor Zaragoza, no logró llegar a su investidura, declinó aquel honor en solidaridad con el estudiante caído y demandó al gobierno de Alemán, llegar a un acuerdo con el movimiento universitario, que diera estabilidad al país. Por tres años se logró el acuerdo y se mantuvo en los gobiernos siguientes, venció la sensatez, la ley y los intereses del país.

El mapa de la conflictividad que vive el país, nos lleva a una honda preocupación, dada su naturaleza, los actores involucrados y la complejidad para avizorar una solución duradera.

1 Director del Instituto "Martin Luther King" de la Universidad Politécnica de Nicaragua (UPOLI). 
El conflicto en Bosawás y en Bilwi encierra un gran potencial de violencia, bastante más que la que ya se viene desarrollando, que involucra a las comunidades indígenas, colonos, intereses empresariales, incluso del narcotráfico que entre otras cosas está destruyendo la Reserva de Biosfera. Todos sabemos que la población indígena de esa región fue un actor en la larga y devastadora guerra de los 80's, es un sector que en 500 años nunca fue vencido y solo cesó aquel conflicto violento después de años de diálogos, mediaciones y negociaciones, que desembocaron en los acuerdos nacionales y regionales de paz. En su caso, la constitución del Estatuto de Autonomía.

En el Caribe Sur, el movimiento campesino que se opone a la construcción del Canal, es evidente que viene ganando fuerza y ampliando la solidaridad de sectores de la clase campesina de otros lugares del país, lo cual explica su organización y funcionamiento mostrado en la última movilización como movimiento cívico por sus reivindicaciones. Fue cuando menos digno de respeto y admiración, no solo la superación de los tantos obstáculos desde sus lejanos lugares de origen hasta la capital, de igual manera su determinación, pero sobre todo su vocación de paz, prefiriendo regresar desde las puertas de la capital sin forzar una confrontación, ni derramamiento de sangre ¿Por qué no se les recibió para conversar y generar confianza, cuando ellos lo primero que reclaman es información? ¿Con quién es que se piensa dialogar entonces? ó ¿Acaso no se contempla el diálogo ante esta conflictividad?. Recordemos que el campesinado fue quien encarnó la contrarrevolución y todo lo que estaba por venir.

\section{La Policía} Nacional, debemos también reconocer que evitó acciones represivas contra el campesinado, aunque sí permitió la intervención de grupos de choque motorizados que a todas luces no son de la Juventud Sandinista y que fueron autores de acciones despreciables por toda la sociedad.

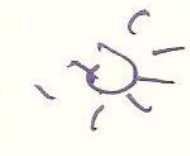

En el Caribe Sur también operan bandas armadas que de acuerdo a la policía son los autores del asesinato de cinco de sus miembros, que no reflejan un perfil político, fundamentalmente por el tipo de acciones que realizan y la ausencia de planteamientos y reivindicaciones de carácter político.

Los informes de CARITAS, dan cuenta de los estragos que viene provocando la sequía en el corredor seco que afecta a más de 10,000 familias de la zona, que viven situaciones de hambruna y de emergencia humanitaria.

Los conflictos de las Minas de Rancho Grande y El Limón, vienen siendo superados. El primero, luego de movilizaciones y una respuesta adecuada del gobierno; en El Limón se entró a conversaciones sólo una semana después de movilizaciones y confrontaciones violentas.

El gobierno del Presidente Ortega, logró acuerdos consensuados tripartitos entre el COSEP, los sectores obreros y el propio Gobierno, que constituyen referencias de abordaje de conflictos y contradicciones potencialmente violentas.

Es importante asumir los métodos de regulación pacíficay creativadelos conflictos, conociendo su naturaleza, sus antecedentes, la legitimidad de intereses que gravitan en ellos, sus actores fundamentales, sus percepciones... La búsqueda consensuada de soluciones a través del diálogo,

la información transparente y la negociación, -para que la sociedad crezca, madure y

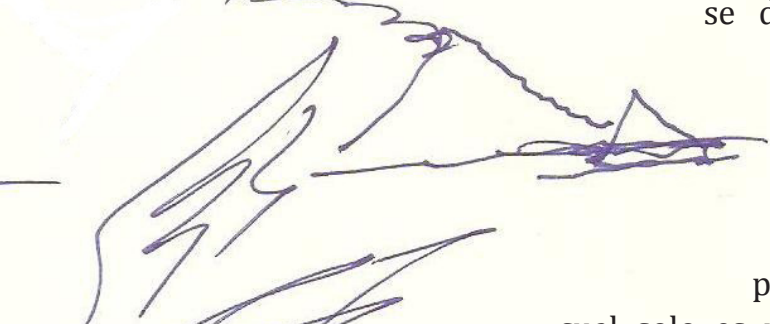
se desarrolle en unidad en la diversidad-, debe ser un mecanismo de gestión gubernamental $\mathrm{y}$ en general, de hacer política en Nicaragua, lo cual solo es posible cuando se acoge, interioriza y se pone en práctica la cultura de la paz. 